\title{
Train-of-four ratio after antagonism of atracur- ium with edrophonium: influence of different priming doses of edrophonium
}

This study was designed to investigate the effect of different priming doses of edrophonium on the relationship between the the recovery of the first twitch of the train-of-four (TI) and train-of-four (TOF) ratio. This relationship was studied after the administration of the full dose of the antagonist in all groups. Edrophonium $1.0 \mathrm{mg} \cdot \mathrm{kg}^{-1}$ was administered either in a single bolus dose (Groupl, controls) or in an initial dose of 0.05 , $0.1,0.15$ or $0.2 \mathrm{mg} \cdot \mathrm{kg}^{-1}$ followed one minute later by the remainder of the $1.0 \mathrm{mg} \cdot \mathrm{kg}^{-1}$ dose in Groups II to V. Reversal was attempted at the ten per cent spontaneous recovery of twitch height (TI) from atracurium-induced neuromuscular blockade. Of all the groups studied, Group $V$ had a significantly greater recovery in the TOF ratio at any given $T 1$ value. When first witch tension (TI) had recovered to 100 per cent of the control, it was found for the same tension that the TOF ratio was greater in Group $V$, being 0.75 compared to 0.63, 0.65, 0.65 and 0.64 in Groups I to IV respectively. The implication is that this differential ability to reverse fade (or prejunctional activity) may be involved in the acceleration of recovery.

\section{Key words}

ANTAGONISTS, NEUROMUSCULAR RELAXANTS:

edrophonium; NEUROMUSCULAR RELAXANTS: atracurium; NEUROMUSCULAR TRANSMISSION: train-of-four.

From the Department of Anesthesiology (41), King Saud University, King Khalid University Hospital, P.O. Box 7805, Riyadh 11472, Saudi Arabia.

Address correspondence to: Dr. M. Naguib.
Our previous reports ${ }^{1-4}$ demonstrated that a marked acceleration of recovery of neuromuscular blockade could be achieved with the administration of edrophonium in divided (priming) sequence.

Bowman ${ }^{5}$ suggested that single twitch depression and train-of-four (TOF) fade are independent effects of neuromuscular blocking drugs, the former being the result of postjunctional block and the latter arising from the action at prejunctional receptors. Different anticholinesterases have different affinities for the presynaptic and postsynaptic sites, in addition to their inhibition of acetylcholinesterase. ${ }^{6}$ The extent of interaction of the priming doses of edrophonium with the above-mentioned binding sites has not been investigated.

This study was designed to compare the effects of different combinations of antagonist priming and the second dose of the antagonist on the relationship between the recovery in the first twitch of the TOF and TOF fade.

\section{Methods}

After institutional approval, 40 ASA physical status I or II adult patients undergoing minor elective procedures were studied. All patients were free from neuromuscular, renal or hepatic disease and were not taking any drugs known to interfere with neuromuscular function. Informed consent was obtained. All patients were premedicated with $0.15 \mathrm{mg} \cdot \mathrm{kg}^{-1}$ diazepam PO 90 minutes preoperatively.

An intravenous infusion of lactated Ringer's solution in 5 per cent dextrose was established prior to induction of anaesthesia. The ECG and nasopharyngeal temperature were monitored continuously by a Medishield Ml monitor. Blood pressure was measured every five minutes by an electronic oscillotonometer (Dinamap).

In all patients, anaesthesia was induced with fentanyl 2 $\mu \mathrm{g} \cdot \mathrm{kg}^{-1}$, thiopentone $5 \mathrm{mg} \cdot \mathrm{kg}^{-1}$ and was maintained with 70 per cent nitrous oxide in oxygen and halothane (0.5-1 per cent). Ventilation was adjusted to maintain normocap- 
nia and end-tidal $\mathrm{CO}_{2}$ was monitored by a Datex infrared $\mathrm{CO}_{2}$ analyzer.

The ulnar nerve was stimulated at the wrist with square wave supramaximal stimuli of $0.2 \mathrm{~ms}$ duration, delivered in a train-of-four (TOF) sequence at $2 \mathrm{~Hz}$ every ten seconds, using a Myotest peripheral nerve stimulator (Biometer). The resultant contraction of the adductor pollicis was recorded using a force displacement transducer and neuromuscular function analyzer (Myograph 2000 Biometer). ${ }^{7}$ Preload tension on the thumb was maintained at $300 \mathrm{~g}$ throughout the investigation.

After stabilization of twitch recording, atracurium $0.5 \mathrm{mg} \cdot \mathrm{kg}^{-1}$ was administered and tracheal intubation was performed at maximum block. Patients were excluded from the study if incremental doses of atracurium were administered.

At the end of surgery, when spontaneous recovery had begun and the first twitch (T1) of the TOF returned to ten per cent of the control value, patients were assigned randomly to one of five groups ( $n=8$ in each). Stratified sampling was used to obtain an even sex distribution. The same total dose of edrophonium $1 \mathrm{mg} \cdot \mathrm{kg}^{-1}$ was given to all patients. In Group I (controls) edrophonium was administered as a single bolus dose. In Groups II to V, edrophonium was administered as an initial dose of 0.05 . $0.10,0.15$, or $0.20 \mathrm{mg} \cdot \mathrm{kg}^{-1}$ respectively followed one minute later by the rest of the dose. In all patients atropine $0.02 \mathrm{mg} \cdot \mathrm{kg}^{-1}$ was administered prior to edrophonium. Patients continue to inhale 70 per cent nitrous oxide in oxygen and 0.5-1 per cent halothane until all measurements were complete. Antagonism of block was considered adequate when a TOF ratio (the amplitude of the fourth to the first evoked response; T4/T1) of 0.75 was attained. ${ }^{8}$ Further assessment of the patients was carried out in the Recovery Room for 60 minutes using clinical criteria such as ability to open eyes, cough and sustain head lift.

The TOF ratios were measured at ten per cent increments of $T 1$ tension after the administration of the second dose of edrophonium in Groups II, III, IV and V, and after the administration of the single dose in Group I.

The following variables were also calculated: (a) TI and TOF ratio just before the administration of the second dose of the antagonist; (b) time for the twitch height (T1) to recover from 25 to 75 per cent of control (recovery index); and (c) reversal time, was the time taken from the first injection of the antagonist until the TOF ratio value had reached 0.75 .

\section{Data processing}

The individual values of TOF ratio after administration of the second dose of edrophonium in Groups II, III, IV and
$V$ and after administration of the single dose in Group I were utilized for linear regression analysis. The independent and dependent variables, respectively, were $\mathbf{T} 1$ and TOF ratio. Linearity of the regression lines was confirmed by the analysis of variance test for linearity. ${ }^{9}$ Then we tested the lines to determine if they deviated from parallelism. If they did not, the pooled slope, b, was calculated. Regression lines were compared using analysis of covariance. The relative positions of the lines were expressed by the calculation of a corrected mean value of $y$ for each group. If the vertical distance between the parallel regression lines was found to be different, a $t$ test was applied to determine which line differed in elevation. ${ }^{9}$

Using analysis of variance, we compared mean age, body weight, $\mathrm{T} 1$ and $\mathrm{TOF}$ ratios before the administration of the second dose of edrophonium, recovery index and reversal time. For all statistical comparisons, differences were considered significant when $\mathrm{p}<0.01$.

\section{Results}

Results are expressed as means $\pm S E M$. There were no significant differences among the five groups with respect to age and body weight (Table I).

Increasing the size of the priming dose of edrophonium from $0.05 \mathrm{mg} \cdot \mathrm{kg}^{-1}$ to $0.20 \mathrm{mg} \cdot \mathrm{kg}^{-1}$ resulted in a greater recovery of $T 1$ and TOF ratio $(p<0.01)$ as shown in Table II.

There was no significant difference in the recovery indices among the groups (Table 11) whether edrophonium was administered as a single bolus (Group I) or in divided doses (Groups II to $\mathrm{V}$ ). Adequate antagonism (a TOF ratio of 0.75 ) was obtained in all patients. Reversal time was significantly faster $(p<0.01)$ in Group $V$ when compared to the control group (Table II).

The test of difference between slopes indicated that the regression lines did not deviate from parallelism. The common slope was highly significant $(\mathrm{p}<0.001)$. The pooled slope, $b$, was estimated to be 0.0055 . Analysis of covariance yielded a significant difference in the position of the lines. The relative position of the lines after the calculation of the corrected mean value of $y$ (TOF ratio) for each group are shown in the Figure. These parallel

TABLE I Demographic data $(n=8$ in each group) (mean \pm SEM)

\begin{tabular}{lcrl}
\hline & $\begin{array}{l}\text { Age } \\
\text { (year) }\end{array}$ & \multicolumn{1}{l}{$\begin{array}{l}\text { Weight } \\
(\mathrm{kg})\end{array}$} & $\begin{array}{l}\text { Sex } \\
(M / F)\end{array}$ \\
\hline Group I & $27 \pm 1.3$ & $62.7 \pm 2.3$ & $4 / 4$ \\
Group II & $30 \pm 2$ & $61.7 \pm 3.8$ & $4 / 4$ \\
Group III & $28.8 \pm 2.4$ & $59.7 \pm 2.9$ & $4 / 4$ \\
Group IV & $28.3 \pm 1.9$ & $64 \pm 2.6$ & $4 / 4$ \\
Group V & $27 \pm 1.5$ & $62.6 \pm 2.5$ & $4 / 4$ \\
\hline
\end{tabular}




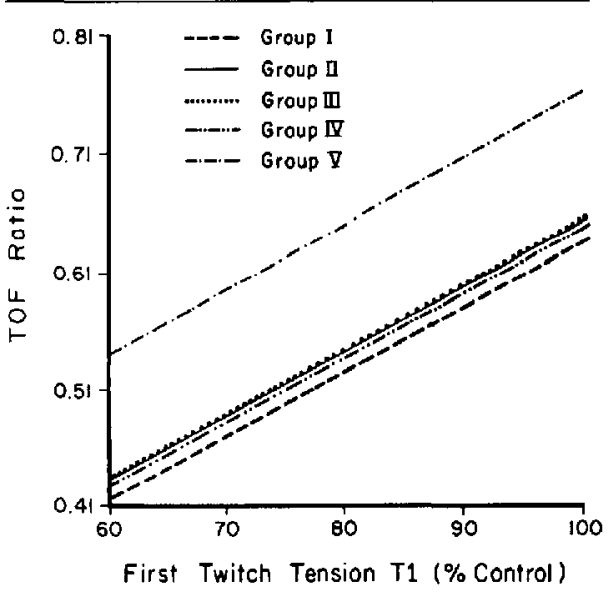

FIGURE Relationship between first twitch height (TI) and train-of-four (TOF) ratio for the five groups studied ( $n=8$ in each) All patients received $1 \mathrm{mg} \cdot \mathrm{kg}^{-1}$ edrophonium in either a single dose (Group I) or an initial dose of 0.05 (Group II), 0.1 (Group III), 0.15 (Group IV) or $0.2 \mathrm{mg} \cdot \mathrm{kg}^{-1}$ edrophonium (Group V) followed one minute later by the rest of the $1 \mathrm{mg} \cdot \mathrm{kg}^{-1}$ dose. The vertical distance for the regression line in Group $V$ was found to be significantly different $(p<0.0001)$ from that in the other groups.

lines (Figure) were drawn through the mean points, each with the same slope, b.

The common slope equations for all groups are:

Group I: $Y_{\mathrm{c}}=0.084+0.0055 \mathrm{x}$

Group II: $Y_{c}=0.101+0.0055 x$

Group III: $Y_{c}=0.102+0.0055 x$

Group IV: $Y_{c}=0.096+0.0055 x$

Group $V: Y_{c}=0.209+0.0055 x$
The subscript $c$ is used to indicate that the predicted values were obtained using the common slope $b$.

The vertical distance for the regression line in Group $\mathrm{V}$ was found to be significantly different $(p<0.0001)$ from that in the other groups. When the first twitch tension (T1) had recovered to 100 per cent of the control, it was found for the same tension that the TOF ratio was greater in Group $V$ being 0.75 compared with $0.63,0.65,0.65$ and 0.64 in Groups I to IV respectively (Figure).

\section{Discussion}

Acetylcholinesterases, as well as neuromuscular blocking drugs, have pre- and postjunctional activity. ${ }^{5,6,10}$ It is believed that these prejunctional nicotinic receptors function in a positive feedback control system that is activated by the transmitter itself and that serves to maintain the availability of acetylcholine when demand for it is high. ${ }^{5,11}$ There is evidence that prejunctional receptors control an ion channel that is specific for sodium. ${ }^{12}$ Sodium is essential for the synthesis and mobilization of the transmitter but it is not directly involved in the release process itself. ${ }^{12}$

Current evidence suggests that atracurium impairs neuromuscular transmission at both presynaptic and postsynaptic sites in the region of the motor end plate. ${ }^{10,13}$ To achieve full recovery of neuromuscular activity, both the pre- and postjunctional depression should be antagonized. We have demonstrated that the antagonism of atracurium induced neuromuscular blockade can be markedly accelerated by divided administration of edrophonium. ${ }^{2-4}$ Whether this acceleration is related to a differential activity of the priming doses at different sites in the neuromuscular junction is not known.

In this study, the same total dose of edrophonium, $1 \mathrm{mg} \cdot \mathrm{kg}^{-1}$, was given to all patients. Therefore, one would predict that after administration of the total dose of

TABLE Il Priming dose, first twitch (T1), tain-of-four (TOF) ratio, recovery index and reversal time (mean \pm SEM)

\begin{tabular}{|c|c|c|c|c|c|}
\hline \multirow[b]{2}{*}{ Group } & \multirow{2}{*}{$\begin{array}{l}\text { Priming } \\
\text { dose } \\
\left(m g \cdot \mathrm{kg}^{-t}\right)\end{array}$} & \multicolumn{2}{|c|}{$\begin{array}{l}\text { Maximum effect of } \\
\text { the priming dose* }\end{array}$} & \multirow[b]{2}{*}{$\begin{array}{l}\text { Recovery index } \\
\text { (sec) }\end{array}$} & \multirow[b]{2}{*}{$\begin{array}{l}\text { Reversal time } \\
\text { (sec) }\end{array}$} \\
\hline & & $\begin{array}{l}T 1 \\
\text { (\% of control) }\end{array}$ & $\begin{array}{l}\text { TOF } \\
\text { ratio }\end{array}$ & & \\
\hline I & - & - & - & $131.2 \pm 40$ & $615 \pm 66$ \\
\hline II & 0.05 & $29.8 \pm 2$ & $0.048 \pm 0.02$ & $64.3 \pm 6.8$ & $399.3 \pm 70$ \\
\hline 11I & 0.10 & $40.5 \pm 1.5 \dagger$ & $0.21 \pm 0.02 \dagger$ & $78.7 \pm 5.8$ & $453.1 \pm 100$ \\
\hline IV & 0.15 & $48.8 \pm 1.9+$ & $0.22 \pm 0.03 \dagger$ & $83.7 \pm 9.8$ & $389.3 \pm 45$ \\
\hline$v$ & 0.20 & $53.8 \pm 2.3 \ddagger$ & $0.43 \pm 0.038$ & $97.8 \pm 21$ & $244.3 \pm 45$ \\
\hline
\end{tabular}

* Just before the administration of the second dose of edrophonium.

tp $<0.01$ as compared with Group II.

$\ddagger p<0.01$ as compared with Group II and III

$\$ p<0.01$ as compared with Group II, JII and IV.

IReversal time was significantly ( $\mathrm{p}<0.01$ ) faster in Group $\mathrm{V}$ when compared with the control group (Group I). 
edrophonium, the relationship between $\mathrm{T} 1$ and $\mathrm{TOF}$ ratio at a given degree of recovery of neuromuscular block would be constant and would not vary with the method of drug administration. However, this was not the case. Therefore, the difference in the TOF ratio and Tl relationships may reflect a difference in prejunctional and postjunctional influences of the priming antagonist on the second dose of the antagonist. Of all the priming doses studied, only $0.20 \mathrm{mg} \cdot \mathrm{kg}^{-1}$, when followed one minute later by $0.8 \mathrm{mg} \cdot \mathrm{kg}^{-1}$ edrophonium was associated with a significantly greater recovery in the TOF ratio at any given $\mathrm{Tl}$ value. If it is supposed that the prejunctional receptors do not have precisely the same configuration as the postjunctional receptors, that is they are isoreceptors of the postjunctional receptors, ${ }^{5}$ then the different selectivity and different rates of binding of different antagonist for the two population of receptors ${ }^{5}$ could explain the response to different priming doses employed in this study.

In the present study, reversal time was significantly faster $(\mathrm{p}<0.01)$ following priming with edrophonium $0.2 \mathrm{mg} \cdot \mathrm{kg}^{-1}$ (Group V) when compared with the control group (Group I). This has been observed before with our previous reports. ${ }^{2-4}$ This is difficult to explain and might indicate that priming with smaller doses of edrophonium was not sufficient to bring about a reduction in the "margin of safety" in enzyme inhibition. ${ }^{14}$ Therefore, no significant acceleration of reversal time and reversal of TOF fade-T1 relationships were observed in the other groups. On the other hand, one might speculate that this response is probably due to unknown pharmacodynamic effect related to acetylcholinesterase enzyme inhibition following priming with doses less than $0.2 \mathrm{mg} \cdot \mathrm{kg}^{-1}$ edrophonium. Although the above explanations do not per se disclose mechanisms, it does furnish a basis for further studies. Further support would come from an intracellular recording technique in which the effect of different dose combinations of edrophonium on the amplitude and frequency of the miniature end-plate potential would be obtained.

The acceleration of recovery of neuromuscular blockade and the significant recovery of TOF fade-T1 relationships were evident only in Group V, and we propose that this is largely a consequence of a prejunctional activity differential following priming with $0.2 \mathrm{mg} \cdot \mathrm{kg}^{-1}$ edrophonium. The prejunctional facilitatory effects of edrophonium are shown to be long lasting. ${ }^{15}$ Direct stimulation of the end-plate region has also been found to contribute to the anticurare action of edrophonium. ${ }^{16}$ In addition, Wachtel recently demonstrated that edrophonium alters the kinetics of ion channels activated by acetylcholine. ${ }^{17}$

The present results indicate that after administration of edrophonium as a single dose of $1 \mathrm{mg} \cdot \mathrm{kg}^{-1}$ or in an initial (priming) dose of $0.05,0.1,0.15, \mathrm{mg}^{\circ} \mathrm{kg}^{-1}$ followed one minute later by the rest of the $1 \mathrm{mg} \cdot \mathrm{kg}^{-1}$ dose, the relationship between the recovery of $\mathrm{T} 1$ and TOF ratio was not significantly different. In contrast, administration of $0.2 \mathrm{mg} \cdot \mathrm{kg}^{-1}$ edrophonium followed one minute later by $0.8 \mathrm{mg} \cdot \mathrm{kg}^{-1}$ edrophonium resulted in a significantly greater recovery of the TOF ratio at any given $\mathrm{T} 1$ value. Acceleration of recovery of neuromuscular blockade was evident only in the latter group; therefore, it can be concluded that prejunctional activity may be involved in the acceleration of recovery.

\section{Acknowledgement}

We thank Mr. Julius P. Caimol from the Medical Illustration Department for his help and Ms. Tess M. Formilleza for typing the manuscript.

\section{References}

1 Abdulatif $M$, Naguib $M$. Accelerated reversal of atracurium blockade with divided doses of neostigmine. Can Anaesth Soc J 1986: 33: 723-8.

2 Naguib $M$, Abdulatif $M$, Absood $G H$. Accelerated reversal of atracurium blockade with priming doses of edrophonium. Anesthesiology 1987; 66: 397-400.

3 Naguib $M$, Abdulatif $M$. Priming with anticholinesterases - The effect of different combinations of anticholinesterases and different priming intervals. Can J Anaesth 1988; 35: 47-52.

4 Naguib $M$, Abdulatif $M$. Priming with anticholinesterases - The effect of different priming doses of edrophonium. Can J Anaesth 1988; 35: 53-7.

5 Bowman WC. Prejunctional and postjunctional cholinoceptors at the neuromuscular junction. Anesth Analg 1980; 59: $935-43$.

6 Donati F, Ferguson A, Bevan DR. Twitch depression and train-of-four ratio after antagonism of pancuronium with edrophonium, neostigmine or pyridostigmine. Anesth Analg 1983; 62: 314-6.

7 Viby-Mogensen J. Clinical evaluation of neuromuscular transmission. Br J Anaesth 1982; 54: 209-23.

8 Ali $H H$, Kitz $R$. Evaluation of recovery from nondepolarizing neuromuscular block using digital neuromuscular transmission analyzer. Preliminary report. Anesth Analg 1973; 52: 740-3

9 Armitage $P$. Statistical methods in medical research. First edition. London: Blackwell Scientific Publications, 1971: 269-301

10 Wali $F A$. Assessment of the presynaptic effect of atracurium. Train-of-four and tetanic stimulation in vitro preparations. Acta Anaesthesiol Scand 1985; 29: 657-62. 
11 Bowman WC, Marshall IG, Gibb AJ. Is there feedback control of transmitter release at neuromuscular junction? Sem Anesth 1984; 3: 275-83.

12 Standaert FG. The doughnut and its hole. Clin Anaesthesiol 1985; 243-59.

13 Otagiri $T$, Sokoll MD. A microelectrode study of the effects of artracurium on neuromuscular transmission. Anesth Analg 1986; 65: 345-9.

14 Barber HE, Calvey TN, Muir KT. The relationship between the pharmacokinetics, cholinesterase inhibition and facilitation of twitch tension of the quaternary ammonium anticholinesterase drugs, neastigmine, pyridostigmine, edrophonium and 3-hydropheny]trimethylammonium. Br J Pharmacol 1979; 66: 525-30.

15 Baker $T$, Stanec A. Prejunctional facilitatory effects of edrophonium. Anesthesiology 1986; 65: A111.

16 Blaber LC, Bowman WC. A comparison between the effects of edrophonium and choline in skeletal muscles in cat. Br J Pharmacol 1959; 14: 456-66.

17 Wachtel RE. Edrophonium alters the properties of ion channels activated by acetylcholine. Anesthesiology 1987; 67: A339.
Résumé

Cette étude a été conçue afin d'investiguer les effets de différentes doses d' amorce d'édrophonium sur la relation entre la récupération du premier twitch de l'ondée-de-quatre (TI) et le rapport de l'ondée-de-quatre (TOF). Cette relation a été étudié après l'administration d'une dose totale de l'antagoniste dans tous les groupes. De l'édrophonium à $1.0 \mathrm{mg} \cdot \mathrm{kg}^{-1} \mathrm{a}$ été administré sait en une dose unique (Groupe 1, contrôle) ou en une dose initiale de $0.05,0.1,0.15$ ou $0.2 \mathrm{mg} \cdot \mathrm{kg}^{-1}$ suivi une minute plus tard par le restant de $1.0 \mathrm{mg} \cdot \mathrm{kg}^{-1}$ de la dose dans les Groupes II d̀ V. L'antagonisme a été essayé après une récupération spontanée à dix pour cent de la hauteur du twitch (TI) après un bloc neuromusculaire induit par l'atracurium. De tous les groupes étudiés, le growpe $V$ avait une récupération significativement plus rapide du rapport de l'ondée-de-quatre a toutes les valeurs de TI. Quand Tl avait récupéré à 100 pour cent du contrôle, on a trouvé que pour la même tension le rapport de l'ondée-de-quatre était plus grand dans le groupe $V$, étant 0.75 comparativemen d $0.63,0.65,0.65$ el 0.64 pour les Groupes I à IV respectivement. Ceci implique la présence d"un mécanisme variable pour l'antagonisme du "fade" (ou activité prejonctionnelle) pour accélérer la récupération. 